\title{
NATION-EMPIRE
}




\section{Studies of the Weatherhead East Asian Institute, Columbia University}

The Studies of the Weatherhead East Asian Institute of Columbia University were inaugurated in 1962 to bring to a wider public the results of significant new research on modern and contemporary East Asia. 


\section{NATION-EMPIRE}

Ideology and Rural Youth

Mobilization in Japan

and Its Colonies

Sayaka Chatani 
Cornell University Press gratefully acknowledges receipt of grants from the Faculty of Arts and Social Sciences and the Department of History, National University of Singapore, which aided in the production of this book.

\section{Copyright () 2018 by Cornell University}

All rights reserved. Except for brief quotations in a review, this book, or parts thereof, must not be reproduced in any form without permission in writing from the publisher. For information, address Cornell University Press, Sage House, 512 East State Street, Ithaca, New York 14850. Visit our website at cornellpress.cornell.edu.

First published 2018 by Cornell University Press

Printed in the United States of America

Library of Congress Cataloging-in-Publication Data

Names: Chatani, Sayaka, author.

Title: Nation-empire : ideology and rural youth mobilization in Japan and its colonies / Sayaka Chatani.

Description: Ithaca : Cornell University Press, 2018.| Series: Studies of the Weatherhead East Asian Institute, Columbia University | Includes bibliographical references and index.

Identifiers: LCCN 2018011988 (print) | LCCN 2018015970 (ebook) | ISBN 9781501730764 (pdf) | ISBN 9781501730771 (epub/mobi) | ISBN 9781501730757 | ISBN 9781501730757 (cloth: alk. paper)

Subjects: LCSH: Rural youth-Political activity-Japan-History20th century. | Rural youth—Political activity—Taiwan-History20th century. | Rural youth—Political activity—Korea (South)— History-20th century. | Young men —Political activity-JapanHistory-20th century. | Young men-Political activity-TaiwanHistory - 20th century. | Young men-Political activity—Korea (South) — History-20th century. | Nationalism-Japan—History-20th century. | Nationalism-Taiwan-History-20th century. | Nationalism-Korea (South)—History—20th century. | Japan—Colonies—History-20th century. Classification: LCC HQ799.8.J3 (ebook) | LCC HQ799.8.J3 C45 2018 (print) | DDC 305.253/091734-dc23

LC record available at https://lccn.loc.gov/2018011988

Cover photograph: Taiwanese trainees of the Xinzhu Province Youth Training Institute, giving a Shinto-style misogi (purification) prayer in the ocean, 1940. Photography courtesy of Xu Chongfa. 
For Zeno, Ash, and Colm 


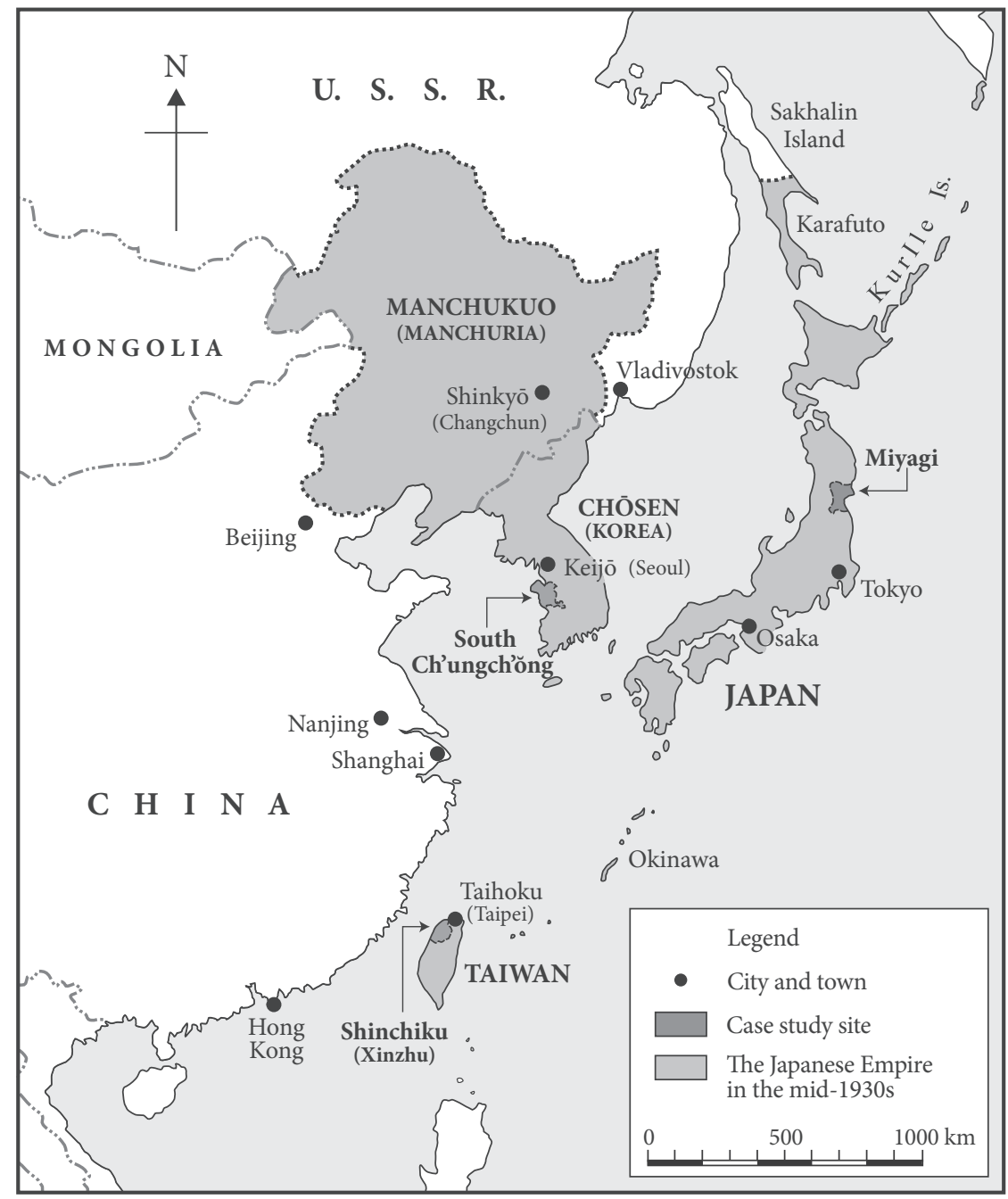

MAP 1. The Japanese Empire in the mid-1930s 